\title{
Kepastian Hukum Penanggulangan Tindak Pidana Penyeludupan Pakaian Bekas
}

\section{Legal Certainty in the Prevention of Criminal Act of Smuggling Used Clothing}

\author{
Ario Putranto*, Triono Eddy \& Alpi Sahari \\ ${ }^{*}$ Program Magister Ilmu Hukum, Universitas Muhammadiyah Sumatera Utara, Indonesia
}

Diterima: Juni 2020; Disetujui: Agustus 2020; Dipublish: Agustus 2020

*Email: arioputranto38@gmail.com

\begin{abstract}
Abstrak
Masalah penyelundupan baik dari segi preventif, represif dan penegakan hukum dalam peningkatan penggunaan produksi dalam negeri dengan fokus pembahasan yaitu: bagaimana Regulasi Terkait Dengan Tindak Pidana Penyelundupan Pakaian Bekas, bagaimana Penanggulangan Terhadap Tindak Pidana Penyelundupan Pakaian Bekas di Indonesia.. Penelitian yang dilakukan adalah penelitian deskriptif dengan metode pendekatan yuridis normatif dilakukan dengan cara studi kepustakaan. Alat pengumpulan data yang digunakan dalam penelitian ini adalah data berupa studi dokumen dan penelusuran kepustakaan. yang menjadi pisau analisis dalam penelitian ini ialah teori kepastian hukum, dan teori kebijakan hukum pidana. Regulasi terkait dengan penyelundupan diatur dalam UndangUndang nomor 10 Tahun 1995 tentang Kepabeanan sebagaimana telah diubah dengan Undang-Undang Nomor 17 Tahun 2006, tepatnya di pasal 102 dan pasal 102A, Keputusan Mentri Perindustrian dan Perdangangan Nomor: 642/MPP/Kep/9/2002 Tentang Perubahan Lampiran 1 Pasal 1 Keputusan Mentri Perindustrian dan Perdagangan No. 229/MPP/Kep/7/1997 Tentang Ketentuan Umum di Bidang Impor. dan juga tertuang dalam Peraturan Mentri Perdagangan No Peraturan Mentri Perdagangan RI No. 51/MDAG/PER/7/2015 Tentang Larangan impor Pakain Bekas. Penanggulangan tindak pidana penyelundupan pakaian bekas secara penal (dengan menerapkan hukum pidana) yang dilakukan oleh penyidik dan atau PPNS adalah dengan melakukan kegiatan penyidikan terhadap penyelundupan.

Kata Kunci: Penyeludupan, Barang Bekas, Penaggulangan
\end{abstract}

\begin{abstract}
The problem of smuggling both in terms of preventive, repressive and law enforcement in increasing the use of domestic production with a focus of discussion namely: how the Regulation is Related to the Criminal Act of Smuggling Used Clothes, how to Prevent the Criminal Acts of Smuggling of Used Clothes in Indonesia .. The research conducted is descriptive research. the normative juridical approach method is done by means of library studies. Data collection tools used in this study are data in the form of document studies and literature searches. which became the knife of analysis in this study was the theory of legal certainty, and the theory of criminal law policy. Regulations related to smuggling are regulated in Law number 10 of 1995 concerning Customs as amended by Law Number 17 of 2006, precisely in article 102 and article 102A, Decree of the Minister of Industry and Trade No. 642 / MPP / Kep / 9 / 2002 Concerning Changes to Attachment 1 Article 1 Decree of the Minister of Industry and Trade No. 229 / MPP / Kep / 7/1997 concerning General Provisions in the Import Sector. and also stated in Minister of Trade Regulation No. RI Minister of Trade Regulation No. 51 / M-DAG / PER / 7/2015 concerning the Prohibition of Imported Used Clothing. Mitigation of the crime of smuggling used clothing (by applying criminal law) carried out by investigators and / or PPNS is to conduct an investigation of smuggling activities.
\end{abstract}

Keywords: Smuggling, Used Goods, Countermeasures

How to Cite: Putranto, A., Eddy, T. \& Sahari, A. (2020). Kepastian Hukum Penanggulangan Tindak Pidana Penyeludupan Pakaian Bekas. Journal of Education, Humaniora and Social Sciences (JEHSS). 3 (1): 39-43. 


\section{PENDAHULUAN}

Luasnya daerah pabean Indonesia yakni seluas wilayah kedaulatan Negara repbulik Indonesia, maka tidak mungkin pemerintah mampu menempatkan semua petugas bea dan cukai (custom) di sepanjang garis perbatasan di seluruh pabean republic Indonesia untuk mengawasi keluar dan masuknya barang dalam rangka kegiatan ekspor dan impor (Sunarno:2007).

Kondisi seperti ini yang menjadi peluang bagi para penyelundupan untuk melakukan kegiatan yang berkaitan dengan impor dan ekspor tanpa membayar bea masuk dan pajak serta bea keluar ke Direktorat jendral Bea dan Cukai. Penyelundupan pada dasarnya merupakan tindak pidana yang berkaitan dengan kegiatan ekspor impor, dimana pelaku melakukan atau mencoba melakukan pengeluaran/pemasukan barang dari atau ke dalam wilayah kepabeanan Indonesia tanpa mengindahkan ketentuan Undang-undang Nomor 17 tahun 2006 tentang perubahan undang-undang nomor 10 tahun 1995 tentang kepabeanan.

Meningkatnya penyeludupan merupakan kendala yang menghambat pembangunan nasional, tindak pidana penyeludupan meningkat oleh faktor luasnya wilayah kepulauan nusantara sehigga banyak pintu masuk dan kelaur yang harus diamankan. Kondisi perekonomian Indonesia di tengah-tengah arus globalisasi, maka diperlukanpersiapan dan perencanaan yang terarah dan matang untuk menjadikan hukum mampu menjawab tantangan masa depan. Seringnya terjadi perubahan kebijaksanaan dibidang ekonomi, sesuai dengan elastisitas tindak pidana ekonom, menuntut aparat penegak hukum harus benar-benar menguasai permasalahan serta tetap dapat mengikuti berbagai perubahan kebijaksanaan tersebut Tambunan, dkk, 2019; Sibarani, dkk, 2019).

Dalam surat keputusan Menteri Perindustrian dan Perdangangan Nomor.229/MPP/Kep7/1997 dan ditambah dengan Peraturan Mentri Perdagangan RI No. 51/MDAG/PER/7/2015 Tentang Larangan impor Pakaian Bekas, ketentuan umum dibidang impor memang disebutkan bahwa "barang yang impor harus dalam keadaan baru kecuali kapal niaga dan kapal ikan". Dalam keputusan tersebut juga disebutkan bahwa," impor hanya boleh dilakukan oleh perusahaan yang telah memiliki angka pengenal importer (API) atau API-Terbatas".

Undang-undang Nomor 17 tahun 2006 tentang perubahan undang-undang nomor 10 tahun 1995 tentang kepabeanan mengatur bahwa Direktorat Jendral Bea dan Cukai bertugas melakukan pengawasan atas lalu lintas barang yang masuk atau keluar daerah pabean.

Penyelundupan pakaian bekas merupakan tindakan yang melanggar ketentuan hukum pidana, sesuai dengan undang-undang No 10 tahun 2005 yang di ubah menjadi Undang-undang No 17 tahun 2006 tentang kepabeanan dan Kepmen Perindak No 229/MPP/Kep/7/2007 Tentang ketentuan umum di bidang impor dan di tambah dengan Peraturan Mentri Perdagangan RI No. 51/M-DAG/PER/7/2015 Tentang Larangan impor Pakaian Bekas.

Tindak pidana penyelundupan pakaian bekas merupakan tindak pidana trans nasional dan saat ini tindak pidana Penyelundupan pakain bekas masih sering terjadi di Indonesia. Saat ini proses penanggulangan tindak pidana Penyelundupan pakaian bekas di Indonesia masih terlihat belum maksimal, hal ini tandai dengan banyaknya penjualan pakaian bekas yang tersebar di wilayah Indonesia. Berdasarkan hal tersebut di atas, maka penulis dalam hal ini akan meneliti lebih lanjut mengenai "Kepastian Hukum Penanggulangan Tindak Pidana Penyelundupan Pakaian Bekas.

\section{METODE PENELITIAN}

Jenis penelitian ini adalah penelitian hukum normatif yang bersifat deksriptif analisis. Bahan hukum primer dalam penelitian ini berupa Undang-Undang No. 172006 tentang Kepabeanan dan Kepmen Perindag No. 229/MPP/Kep/7/2007 tentang Ketentuan Umum di Bidang Impor. Bahan hukum sekunder bersumber dari buku-buku, jurnal dan tulisan yang relevan dengan pokok permasalahan dalam penulisan ini. Metode pengumpulan data melalui studi kepustakan (library research) serta menggunakan alat pengumpulan data berupa studi dokumen dengan menganalisisnya secara kualitatif. 


\section{HASIL DAN PEMBAHASAN}

\section{Penanggulangan Terhadap Tindak Pidana Penyeludupan Pakaian Bekas di Indonesia}

Penanggulangan Terhadap Tindak Pidana Penyeludupan Pakaian Bekas di Indonesia dapat dilakukan dengan kebijakan penal. Menurut Scoorates kebijakan adalah pengetahuan dan pengetahuan adalah kebijakan (Souryal, 2005). Kata kebijakan (Policy Beliend) di gunakan oleh Barda Nawawi Arief sebagai kebijakan Legislatif untuk merumuskan ulang atau reformulasi pengaturan sanksi pidana penjara dalam undang-undang pidana sebagai bahan penyempurnaan atau penyusunan kembali kebijakan legislatife (Nawawi, 1996). Maka Kebijakan yang di maksud dalam tulisan ini, yaitu kebijakan legislatife dalam menyusun formulasi undang-undang.

Kebijakan yang di maksud adalah kebijakan kriminal dalam penanggulangan kejahatan (politik kriminal) dilakukan dengan menggunakan sarana penal (hukum pidana), maka, Kebijakan Hukum Pidana khususnya pada tahapan kebijakan yudikatif atau aplikatif (penegakan hukum pidana in concreto) harus memperhatikan dan mengarah pada tercapainya tujuan dari kebijakan sosial itu berupa social welfare dan social define dan penanggulangan kejahatan dengan srana Penal merupakan Penal Police atau Penal Law Envorcement Policy yang fungsional dan operasional (Nawawi, 2007).

Kebijakan hukum pidana dapat diartikan dengan cara bertindak atau kebijakan dari negara (pemerintah) untuk menggunakan hukum pidana dalam mencapai tujuan tertentu, terutama dalam menanggulangi kejahatan, memang perlu diakui bahwa banyak cara maupun usaha yang dapat dilakukan oleh setiap negara (pemerintah) dalam menanggulangi kejahatan. Salah satu upaya untuk dapat menanggulangi kejahatan, diantaranya melalui suatu kebijakan hukum pidana atau politik hukum pidana (Wisnubroto, 1999). Menurut Marc Ancel, pengertian penal policy (Kebijakan Hukum Pidana) adalah suatu ilmu sekaligus seni yang pada akhirnya mempunyai tujuan praktis untuk memungkinkan peraturan hukum positif dirumuskan secara lebih baik dan untuk memberi pedoman tidak hanya kepada pembuat undang-undang, tetapi juga kepada pengadilan yang menerapkan undang-undang dan juga kepada penyelenggara atau pelaksana putusan pengadilan (Nawawi, 2010).

Untuk hal mencapai tujuan tertentu hukum pidana tidak dapat bekerja sendiri, tetapi perlu melibatkan sarana-sarana lainnya yang mendukung, yakni tahapan kebijakan hukum pidana, dalam mengoperasionalkan hukum pidana, melalui tahap formulasi kebijakan legislatif atau pembuatan peraturan perundang-undangan, tahap perencanaan yang seharusnya memuat tentang hal-hal apa saja yang akan dilakukan, dalam mengadapi persoalan tertentu dibidang hukum pidana, dan kejahatan yang terjadi selalu berorientasi pada kebijakan penanggulangan kejahatan terpadu, sebagai upaya yang rasional guna pencapaian kesejahteraan masyarakat dan sekaligus perlindungan masyarakat (Bakhri, 2009).

Perencanaan (planning) pada tahapan formulasi pada intinya, menurut Nils Jareborg mencakup tiga masalah pokok struktur hukum pidana, yaitu (Jareborg, 2007) masalah Perumusan tindak pidana/kriminalisasi dan pidana yang diancamkan (criminalisation and threatened punishment); Pemidanaan (adjudication of punishment sentencing); Pelaksanaan pidana (execution of punishment).

Kebijakan hukum pidana berkaitan dengan masalah kriminalisasi yaitu (Prasetyo, 2011) perbuatan apa yang dijadikan tindak pidana dan penalisasi yaitu sanksi apa yang sebaiknya dikenakan pada si pelaku tindak pidana. Kriminalisasi dan penaliasi menjadi masalah sentral yang untuk penanganannya diperlukan pendekatan yang berorientasi pada kebijakan (policy oriented approach).

Kriminalisasi (criminalisation) mencakup lingkup perbuatan melawan hukum (actus reus), pertanggungjawaban pidana (mens rea) maupun sanksi yang dapat dijatuhkan baik berupa pidana (punishment) maupun tindakan (treatment). Kriminalisasi harus dilakukan secara hati-hati, jangan sampai menimbulkan kesan represif yang melanggar prinsip ultimum remedium (ultima ratio principle) dan menjadi bumerang dalam kehidupan sosial berupa kriminalisasi yang berlebihan (oever criminalisation), yang justru mengurangi wibawa hukum. Kriminalisasi dalam hukum 
pidana materiil akan diikuti pula oleh langkah-langkah pragmatis dalam hukum pidana formil untuk kepentingan penyidikan dan penuntutan (Muladi, 2003).

Menurut M. Hamdan, upaya penaggulangan yang merupakan bagian dari kebijakan sosial pada hakikatnya juga merupakan bagian integral dari upaya perlindungan masyarakat (social defence) yang dapat ditempuh dengan 2 jalur, yaitu : Jalur penal, yaitu dengan menerapkan hukum pidana (criminal law application), jalur non penal, yaitu dengan cara :pencegahan tanpa pidana (prevention without punisment), termasuk di dalamnya penerapan sanksi administrative dan sanksi perdata, mempengaruhi pandangan masyarakat mengenai kejahatan dan pembinaan lewat media massa (influencing views of society on crime and punishment).

Tindakan hukum dikatakan "efektif" ketika perilaku bergerak kearah yang dikehendaki, Ketika subyek patuh atau menurut, banyak tindakan hukum tidak "efektif" dalam pengertian ini. Orang-orang mengabaikan atau melanggar ketentuan.Lazimnya sanksi dibagi menjadi dua bagian, imbalan dan hukuman, yakni sanksi positf dan negatif. Gagasannya adalah bahwa orang-orang yang menjadi subyek hukum akan memilih satu dan menghindari yang lainnya. Para pembuat hukum berasumsi bahwa sanksi yang berlabel "hukuman" adalah bersifat menyakitkan dan "imbalan" adalah yang bersifat menyenangkan, sehingga konsekuensi perilaku yang dikehendaki akan mengikuti secara otomatis. Bentuk-bentuk hukuman yang lazim dalam hukum pidana adalah denda dan kurungan. Hukuman fisik atau hukuman jasmaniah lainnya, pada masa lalu sering digunakan dalam hukum (Raharjo, 2009).

\section{Pertanggungjawaban Hukum Terhadap Pelaku Penyeludupan Pakaian Bekas}

Kepastian hukum sangat erat kaitanya dengan validitas norma dalam aturan, dalam hal ini Bruggink membagi validitas (keberlakuan norma) menjadi tiga bagian. Pertama: validitas faktual, kedua: validitas normatif, ketiga: validitas evaluatif. Jika ditarik pemahaman tentang validitas dapat diartikan, Validitas adalah eksitensi norma secara spesifik. Suatu norma adalah valid merupakan suatu peryataan yang mengasumsikan eksistensi norma tersebut dan mengasumsikan bahwa norma itu memiliki kekuatan mengikat (binding force) terhadap orang yang perilakunya diatur. Aturan adalah hukum, dan hukum yang jika valid adalah norma. Jadi hukum adalah norma yang memberikan sanksi (Asshiddiqie, 2006).

Undang-undang dan aturan hukum terkait tindak pidana penyelundupan sudah jelas, dimana dalam konteks ini termasuk penyelundupan pakaian bekas. Pemasukan pakaian bekas kedalam NKRI dilarang sebagaimana yang diatur dalam pasal 2 Permendag Nomor 51/MDAG/PER/7/2015 tentang Larangan Impor Pakaian Bekas. Dengan demikian ada konsukuensi hukum apabila ada upaya para penyelundup untuk memasukkan pakaian bekas ke dalam NKRI yaitu sebagaimana yang diatur dalam pasal 102 dengan sanksi pidana berupa penjara paling singkat 1 (satu) tahun dan pidana penjara paling lama 10 (sepuluh) tahun dan pidana denda paling sedikit Rp50.000.000,00 (lima puluh juta rupiah) dan paling banyak Rp5.000.000.000,00 (lima miliar rupiah).

Dalam hal pemberian sanksi, terdapat kelemahan karena Undang-undang itu hanya memberikan sanksi administratif kepada importir yang melanggar. Ini sering dijadikan 'permainan' untuk keuntungan pribadi," berikut beberapa kelemahan dalam undang-undang kepabeanan : penegakan hukum paling efektif mungkin adalah dengan memberikan sanksi atas pelanggaran yang diatur oleh hukum tersebut. Kepabeanan dan cukai sepertinya juga menganut paham yang serupa. Pada beberapa peraturan banyak didapati pasal yang mengatur tentang sanksi. Ada sanksi pidana dan ada juga sanksi administrasi. Namun, karena bea cukai adalah institusi yang banyak berkaitan dengan dunia usaha yang dijalankan dengan 'duit' maka sepertinya sanksi-administrasi-berupa-denda lebih banyak diperbincangkan. Kali ini kita akan membahas tentang Sanksi Administrasi di Bidang Kepabeanan.

Dalam terminologi kepabeanan dan cukai, sanksi dibagi menjadi dua jenis: sanksi pidana dan sanksi administrasi. Sanksi pidana ini juga masih terbagi menjadi dua, yaitu sanksi pidana pabean dan sanksi pidana cukai. Sanksi pidana pabean diatur dalam undang-undang kepabeanan yaitu Undang-Undang Nomor 10 Tahun 1995 yang telah diubah dengan Undang-undang Nomor 17 Tahun 2006. Ketentuan tentang pidana kepabeanan lebih tepatnya terletak pada Bab XIV pada Wwit http://mahesainstitute.web.id/ojs2/index.php/jehss 
pasal 102 sampai dengan pasal 111. Sedangkan sanksi pidana cukai diatur dalam Undang-undang Nomor 11 Tahun 1995 tentang Cukai yang telah diubah dengan Undang-undang Nomor 39 Tahun 2007. Ketentuan tentang tindak pidana di bidang cukai ini diatur dalam Bab XII pasal 50 sampai dengan pasal 62. Kedua sanksi pidana, baik pabean maupun cukai, sudah secara jelas tersurat pada kedua undang-undang berikut perubahan dan penjelasannya, oleh karenanya (setahu kami) tidak ada peraturan yang lebih spesifik mengaturnya lagi.

Terhadap pelaku tindak pidana penyelundupan perlu dikenakan sanksi pidana yang bersifat alternatif agar Undang-Undang Kepabeanan dilaksanakan dan ditaati untuk meningkatkan pendapatan dan devisa negara. Jika sanksi pidana tidak diformulasi secara kumulatif maka aspek kepentingan penerimaan keuangan negara tidak diutamakan, karena sanksi pidana yang bersifat kumulatif hanya sebatas dimaksudkan untuk menegakkan kewibawaan pemerintah, dengan mengabaikan kepentingan yang lebih besar mengutamakan pengembalian kerugian negara.

\section{SIMPULAN}

Penanggulangan tindak pidana penyelundupan pakaian bekas secara penal (dengan menerapkan hukum pidana) yang dilakukan oleh penyidik dan atau PPNS adalah dengan melakukan kegiatan penyidikan terhadap penyelundupan. Kegiatan penyidikan ini hukum dapat ditegakkan sehingga memberikan efek jera kepada para pelaku penyelundupan pakaian bekas, Melaksanakan kegiatan patroli laut secara rutin baik dengan skema patroli mandiri, patroli terkoordinasi dan patroli perbantuan, Melakukan pendekatan kepada masyarakat secara personal.

Kepastian hukum merupakan keadaan dimana perilaku manusia berada dalam koridor yang sudah digariskan oleh aturan hukum, hal ini yang belum terujjud, karena jika dilihat fakta di lapangan masih banyaknya terjadi praktek penjualan pakaian bekas di pasaran, sehingga dapat di simpulkan bahwa terjadi ketidakpastian hukum terhadap penanggulangan tindak pidana penyelundupan pakaiana bekas di indonesia.

\section{DAFTAR PUSTAKA}

Asshiddiqie, J. dan Safa'at, A. (2006). Teori Hans Kelsen Tentang Hukum: Konstitusi Press. Jakarta Bakhri, S. (2009). Muladi dalam Pidana Denda dan Korupsi, Total Media Yogyakarta,

Muladi, (2003). Kebijakan Kriminal terhadap Cybercrime, Majalah Media Hukum Vol. 1 No. 3 tanggal 22 Agustus 2003

Nawawi, B,A.. (1996). Kebijakan Legislatif Dalam Penanggulangan Kejahatan Dengan Pidana Penjara, Semarang: Badan Penerbit Universitas Diponegoro,

Nawawi, B.A.. (2010). Bunga Rampai Kebijakan Hukum Pidana, Bandung: PT. Citra Aditya Bakti

Nawawi, B.A.. (2007). Masalah Penegakan Hukum dan Kebijakan Hukum Pidana dalam Penanggulangan Kejahatan, Jakarta: Kencana Media Group.

Prasetyo, T. (2011). Kriminalisasi dalam Hukum Pidana, Nusa Media. Jakarta

Rahardjo, S. (2009), Hukum dan Prilaku: Hidup Baik adalah Dasar Hukum yang Baik, Jakarta: Penerbit Buku Kompas.

Sibarani, A. Arifin, S. \& Siregar, T. (2019). Analisis Hukum Pidana Terhadap Penanggulangan Kejahatan Illegal Logging Di Provinsi Riau (Studi Kasus di Pengadilan Negeri Pekanbaru) ARBITER: Jurnal Ilmiah Magister Hukum, 1(1) 2019: 19-30.

Souryal. S.S. (2005). Ethick In Criminal Justice (Etika Dalam Peradila Pidana, upaya mencari kebenaran), Sam Houston State Univercity US, Penerbit PT. Cipta Manunggal Edisi Ke-2;

Tambunan, R, Suhatrizal \& Siregar, T. (2019). Penegakan Hukum Terhadap Tindak Pidana Kepabean Penyeludupan Pakaian Bekas (Putusan No. 237/Pid.B/2016/PN.Tjb). JUNCTO, 1(2) 2019: 158-165,

Wisnubroto, A. (1999). Kebijakan Hukum Pidana dalam Penanggulangan Penyalahgunaan Komputer, Universitas Atmajaya Yogyakarta. 